\title{
Assessment of Patient, Family and Staff Satisfaction in a Mental Health Service ${ }^{1}$
}

\author{
Kênia Izabel David Silva de Resende ${ }^{2}$ \\ Universidade Federal de São João \\ del-Rei, São João del Rei-MG, Brazil
}

\author{
Marina Bandeira \\ Universidade Federal de São João \\ del-Rei, São João del Rei-MG, Brazil
}

\author{
Daniela Carine Ramires Oliveira \\ Universidade Federal de São João \\ del-Rei, São João del Rei-MG, Brazil
}

\begin{abstract}
Psychosocial Care Centers (CAPS) provide care to people with psychiatric disorders and aim to reinsert them into the community. Assessing these services is important to maintaining quality. This study assessed the satisfaction level of 84 patients, 84 family caregivers and 67 professionals from a large center of mental health care center (CAPS-III). Structured interviews were individually held by applying the Satisfaction with Mental Health Services Scales (SATIS-BR) and socio-demographic questionnaires. Overall scores were high for family caregivers and moderate for the patients and professionals. The family caregivers were satisfied with all the service's dimensions; patients were satisfied with help received, and professionals were satisfied with their relationships with co-workers. Patients were dissatisfied with the service's infrastructure, while professionals were dissatisfied with working conditions and infrastructure. The results indicate a need for investment in the service's infrastructure and to improve working conditions.
\end{abstract}

Keywords: mental health service, community mental health, public health services, satisfaction

\section{Avaliação da Satisfação dos Pacientes, Familiares e Profissionais com um Serviço de Saúde Mental}

\begin{abstract}
Resumo: Os Centros de Atenção Psicossocial (CAPS) visam o tratamento de pessoas com transtornos psiquiátricos e sua reinserção na comunidade. As avaliações destes serviços são importantes para a manutenção da sua qualidade. Este estudo avaliou a satisfação de 84 pacientes, 84 familiares e 67 profissionais com um CAPS III. Foram realizadas entrevistas individuais estruturadas, com aplicação das Escalas de Satisfação com os Serviços de Saúde Mental (SATIS-BR) e questionários sociodemográficos. Os escores globais de satisfação foram elevados para os familiares e moderados para os pacientes e profissionais. Os familiares estavam satisfeitos com todas as dimensões do serviço, os pacientes com a dimensão do acolhimento e os profissionais com o relacionamento entre colegas no trabalho. Pacientes e profissionais estavam insatisfeitos com a infraestrutura e os profissionais com as condições de trabalho. Os resultados apontaram para a necessidade de investimentos em infraestrutura e a melhoria das condições de trabalho dos profissionais.
\end{abstract}

Palavras-chave: serviços de saúde mental, saúde mental comunitária, serviços de saúde pública, satisfação

\section{Evaluación de la Satisfacción de los Pacientes, Familiares y Profesionales con un Servicio de Salud Mental}

\begin{abstract}
Resumen: Los Centros de Atención Psicosocial (CAPS) son servicios comunitarios para el tratamiento de las personas con trastornos psiquiátricos e su integración en la comunidad. Las evaluaciones de estos servicios son importantes para mantener la calidad. Evaluó la satisfacción de 84 pacientes, 84 familiares y 67 profesionales de un centro de referencia en salud mental (CAPS III). Fueron realizadas entrevistas individuales estructuradas, con aplicación de las Escalas de Satisfacción con El Servicio de Salud Mental (SATIS-BR) y cuestionarios sociodemográficos. Los escores globais foram altos para os familiares e moderados para los pacientes e profesionales. Los familiares estaban satisfechos con todas las dimensiones del servicio, los pacientes estaban satisfechos con la acogida y los profesionales con la relación entre compañeras en el trabajo. Los pacientes e profesionales estaban insatisfechos con la infraestrutura y los profesionales con las condiciones de trabajo. Los resultados mostraron la necesidad de inversiones en infraestructura de los serviços y la mejora de las condiciones de trabajo.
\end{abstract}

Palabras clave: servicios de salud mental, salud mental comunitaria, servicios de salud pública, satisfacción

\footnotetext{
${ }^{1}$ This paper is derived from the master's thesis of the primary author under the supervision of the second author. It was defended in 2015, in the Graduate Program in Psychology at the Universidade Federal de São João del-Rei (PPGPSI-UFSJ).

Support: Foster Program directed to the Graduate Program at the Universidade Federal de São João del-Rei (PIPG-UFSJ) Decree/MEC 2.684, from September 25, 2003 (Report n. 006 de 25/02/2013 CONDI-UFSJ).

${ }^{2}$ Correspondence address:

Kênia Izabel David Silva de Resende. Rua Santa Catarina, 603/202, Senhora das Graças. CEP 32604-625. Betim-MG, Brazil. E-mail: keniaizabel@ gmail.com
}

Psychiatric Reform, implemented according to Law No. 10,216 (2001), profoundly changed Brazilian public health policies so that treatment protocols for psychiatric patients, the role of families, and the practice of healthcare workers changed, as well. The treatment of patients no longer prioritized symptoms but also addressed functional recovery, focusing on autonomy, independence, social reinsertion and quality of life (Cardoso, 2014; Delgado et al., 2007; 
Thornicroft \& Tansella, 2010). The participation of families became essential for the attainment of these goals. One relative became the primary informal caregiver of patients, providing assistance in daily living activities, administering medication, supervising problematic behavior, and supporting the autonomy of patients (Barroso, 2014; Tessler $\&$ Gamache, 2000). The family caregiver is, therefore, able to assess improvement presented by the patient in response to the treatment and to collaborate in the treatment designed by health providers (Bandeira, Silva, Camilo, \& Felício, 2011; Perreault, Rousseau, Provencher, Roberts, \& Milton, 2011). The responsibilities of the mental health staff became more diversified and intensified (Bandeira, 2014; Rebouças, Legay, \& Abelha, 2007; Santos et al., 2011). Healthcare workers became responsible for a larger number of patients' needs concerning more varied interventions, for dealing with a new work context, both clinical and organizational, and supporting families in their new roles as informal caregivers (Ishara, Bandeira, \& Zuardi, 2014; Leal, Bandeira, \& Azevedo, 2012).

Assessing, monitoring and ensuring the quality of new treatment devices in the mental health services became essential (Bandeira, 2014; Kantorski, 2012; Oliveira et al., 2014; Silva, Melo, \& Esperidião, 2012). In Brazil, CAPS (Psychosocial Care Centers) became dedicated mental health centers within the public network, providing community treatment to people with severe and persistent psychiatric disorders. These centers are important components of the Psychosocial Care Network, connecting different devices within the health network, such as primary health care and hospital care, among other services, such as Living Centers and Therapeutic Residential Services (STR) (Costa, Figueiró, \& Freire, 2014).

The services can be assessed at three levels: structure, process and results (Donabedian, 1990) and this study presents an assessment of the results. The level of results is related to the effects of interventions and treatments on the health and lives of patients (Donabedian, 1990). At this level, changes perceived by patients, their level of satisfaction, impact perceived on their quality of life, and more importantly, whether their needs are met, can be verified (Donabedian, 1990). The results should be assessed through reliable subjective and objective measures (Ruggeri, 2010). Among the subjective measures, satisfaction is considered the best indicator of quality of care (Ruggeri, 2010). The satisfaction of patients has been associated with improved treatment adherence, more frequent use of services, and a low rate of treatment abandonment (Einsen, 2010; Ruggeri, 2010). Information obtained from satisfaction surveys enable the reorganization of health care, and the improvement of quality of treatments and interventions. As a consequence, they contribute to the quality of life of those using the services (Ruggeri, 2010).

Satisfaction is considered a multidimensional construct that requires multifactorial instruments to measure it accurately (Ruggeri, 2010). Multifactorial instruments present subscales that detect specific dimensions regarding satisfaction and dissatisfaction (Bandeira \& Silva, 2012;
Silva, 2014). Certain requirements, such as psychometric features of validity and reliability, need to be met for satisfaction assessments to have credibility (Bandeira \& Silva, 2012).

Various studies have assessed mental health services using satisfaction measures and most focused on patient satisfaction (Blenkiron \& Hammill, 2003; Gani et al., 2011; Heckert, Teixeira, \& Trindade, 2006; Holikatti et al., 2012; Kantorski et al., 2009; Silva, Bandeira, Scalon, \& Quáglia, 2012), followed by that of healthcare providers (De Marco, Cítero, Moraes, \& Nogueira-Martins, 2008; Evans et al., 2006; Hannigan, Edwards, Coyle, Fothergill, \& Burnard, 2000; Ishara et al., 2014; Pelisoli, Moreira, \& Kristensen, 2007; Rebouças et al., 2007). The satisfaction of families was the least studied (Bandeira et al., 2011; Perreault et al., 2011; Santos \& Cardoso, 2014; Stengard, Honkonen, Koivisto, \& Salokangas, 2000). In recent years, the World Health Organization (WHO, 2001) has encouraged assessments from multiple or integrative perspectives, including the simultaneous participation of all stakeholders: patients, their families, and the workers responsible for providing care. This type of assessment is considered the most appropriate for examining the complexity of these services (Thornicroft \& Tansella, 2010; WHO, 2001).

We found two studies, an international and a Brazilian one, published in indexed scientific periodicals, simultaneously assessing the satisfaction of patients, their families and mental health service workers, using validated instruments (Camilo, Bandeira, Leal, \& Scalon, 2012; Lasalvia et al., 2012). The Brazilian study was conducted in a small service (CAPS I) with the capacity for care delivery and interventions, with a different number of professionals than that of the service assessed in this study. Due to a lack of studies assessing services from multiple perspectives, this study's objective was to assess the satisfaction of patients, their families, and professionals from a CAPS III.

\section{Method}

\section{Participants}

This study's target population was composed of patients, their families, and the healthcare workers of a CAPS III from a city of approximately 375,000 inhabitants in the Southern region of Brazil. The three samples totaled 235 participants. A non-probabilistic, accidental sampling was used. In this type of sampling, the subjects are recruited based on their presence in specific place and time (Contandriopoulos, Champagne, Potvin, Denis, \& Boyle, 1994); in this case, it was days patients attended psychiatric appointments at CAPS. The sample size was determined by statistical computations, seeking a statistical power of $90 \%$ (Snedecor \& Cochran, 1971). A total of 84 patients with diagnoses of schizophrenia, schizotypal disorders, delirious disorders (F20 to F29), or mood or affective disorders (F30 to F39), participated in the study. The diagnoses were obtained from the service's medical records and were classified according to the International Classification of Diseases (ICD-10) (WHO, 
1994).Inclusion criteria were being 18 years old or older, both genders, attending the psychiatric appointment accompanied by a family caregiver, and undergoing treatment at the service for at least three months. This minimum duration of treatment was adopted because, according to Melo and Guimarães (2005), it is shorter than the period in which most patients abandon treatment (four months). Exclusion criteria included severe psychiatric comorbidities, such as the use of psychoactive drugs or alcohol, cognitive deficits, neurological problems and difficulty in understanding the questions contained in the instruments used. The sample of family caregivers was conditioned on the sample of patients, so that one family caregiver was selected for each participant patient. A total of 84 family caregivers were included according to the following inclusion criteria: being 18 years old or older; living in the same residence as the patient; and being the primary caregiver. Family caregivers who found it difficult to understand the instruments' questions or presented psychiatric disorders, as indicated by the services' professionals, were excluded. The entire target population working in the service was used to select the professionals at the time of data collection. A total of 67 workers who met the inclusion criteria (having worked in the service for at least six months) were included.

\section{Instruments}

Satisfaction with Mental Health Services Scales (SATIS-BR), versions for patient, family caregiver and staff. These instruments were developed in a multicenter study conducted by the World Health Organization's Department of Mental Health and validated for Brazil (Bandeira, Mercier, Perreault, Libério, \& Pitta, 2002; Bandeira, Pitta, \& Mercier, 2000; Bandeira \& Silva, 2012). The SATIS-BR/ Patients has 12 items distributed into three subscales: (1) Staff expertise and understanding; (2) Staff's helpfulness and the helpfulness of the services received; (3) Service's appearance and level of comfort. The SATIS-BR/Family caregiver has eight items distributed into three subscales: (1) Results of treatment provided by the service; (2) Staff's helpfulness and expertise; and (3) Service's privacy and confidentiality. The SATIS-BR/Staff has 32 items grouped into four subscales: (1) Quality of services provided to patients; (2) Participation in the service; (3) Working conditions; and (4) Relationship at work. Answers for the three scales are classified on a five-point Likert scale according to the following: 1 = very dissatisfied, $2=$ dissatisfied, $3=$ regular, $4=$ satisfied, and $5=$ very satisfied . These five options for answers can be grouped into three categories in which 1 and 2 represent very dissatisfied and dissatisfied, 3 represents moderately satisfied, and 4 and 5 represent satisfied and very satisfied with the aspects under assessment. All the scales present appropriate psychometric qualities. Reliability was verified through internal consistency analysis using Cronbach's alpha, which presented the following values for the overall scores in each of the scales: SATIS-BR/Patients, .88; SATIS-BR/Family caregivers, .79; SATIS-BR/Staff, .89.
Sociodemographic questionnaires, in three versions, were prepared: one for each of the samples. The questionnaires were developed by LAPSAM (Laboratory of Research in Mental Health) at the Universidade Federal de São João del-Rei (UFSJ), based on the literature in the field. The questionnaires were submitted to a pilot-study intended to assess its adequacy for and comprehension on the part of the populations under study.

\section{Procedure}

Data collection. The interviewers were previously trained to apply the instruments in order to standardize application. The patients and families were informed about the study on the day they attended their psychiatric appointment at CAPS and were invited to participate after it. The instruments were applied in individual interviews held at the mental health service. According to inclusion criteria, only patients accompanied by a family caregiver were interviewed. The Probing Technique was used to verify the level of understanding of both patients and family caregivers regarding the instruments. In this technique, the respondents are asked to explain each of their responses. This allows the interviewers to verify whether the questions were properly understood (Guillemin, Bombardier, \& Beaton, 1993). The staff members were contacted at the mental health service and self-administered the instruments during work breaks or at the end of the workday.

Data analysis. Data analysis was performed using SPSS, version 20.0. Descriptive statistical analyses were conducted, including means, standard deviations, and percentage to describe the samples and satisfaction scores. Non-parametric tests were used for the statistical analysis of samples. Intragroup analyses were conducted to compare subscales of satisfaction and identify the dimensions that presented the highest scores for each group. For that, the Kruskal-Wallis and multiple comparison tests (Siegel \& Castellan, 2006) were used to identify differences among subscales.

\section{Ethical Considerations}

This study was approved by the Institutional Review Board (CEPES) at the Universidade Federal de São João del-Rei (UFSJ, Process n. 023/2013) and by DESA (Board of Education in Health), the agency responsible for the mental health service under study. The participants signed free and informed consent forms. The study's objectives and procedures were clarified and confidentiality of both participants' identities and information provided were ensured according to Resolution n. 466, from December 12, 2012, National Council of Health.

\section{Results}

\section{Description of the Samples}

The average age for the sample of patients was 43.46 years old, ranging from 20 to 65 years old. Most were women 
(51.20\%), single $(54.7 \%)$, presented incomplete primary or middle school (50\%), had no paid job $(86.90 \%)$, had their own income (63.1\%) of 1 times the minimum wage $(50.9 \%)$, provided by Social Security (34\%). In regard to the patients' clinical characteristics, most were diagnosed in category F20 (69\%), presented psychiatric comorbidities $(83.3 \%)$, and had no physical diseases (64.3\%). In regard to the patients' clinical histories, the average age of the patients at the onset of the psychiatric disorder was 26.55 years old and the duration of treatment was 10.23 years on average. Most had not experienced psychiatric episodes in the last year (53.6\%) and were never committed to a psychiatric hospital (73.8\%). Among those who had been hospitalized, $40.9 \%$ were hospitalized only once. All the patients received psychiatric care with the administration of medication and 39.3\% also received psychological support. Most (72.6\%) took oral medication and administered the medication themselves.

In regard to the sample of family caregivers, the average age was 51.48 years old, ranging from 22 to 84 years old. Most were women (73.8\%), married (57.1\%), with children $(91.7 \%)$, were the mothers $(41.7 \%)$ of patients, while incomplete primary or middle school predominated (46.4\%). Most had a paid job (56\%), their own income (76.2\%), below 2 times the minimum wage (35.9\%), and the primary source of income was their jobs (54.7\%). In regard to the family caregivers' conditions of life, most cared for the patients for more than 11 years $(59.5 \%)$, had some physical disease $(60.7 \%)$, and reported already feeling ill because of the task of providing care to the patient (65.5\%). Most reported other concerns/activities besides caring for the patient (73.8\%), having received information regarding the problem presented by the patient $(65.5 \%)$, and that the information provided was mostly provided by healthcare providers $(92.7 \%)$. Most reported they could rely on the mental health service whenever needed $(92.7 \%)$.

In regard to the staff, the average age was 41.28 years old, ranging from 24 to 60 years old. Most were women $(70.10 \%)$, single $(50.70 \%)$, were nursing technicians $(41.8 \%)$, followed by psychiatrists $(16.4 \%)$ and nurses $(11.9 \%)$, respectively. Most had from one to five years of experience in the mental health service $(52.2 \%)$, had a workload of 30 hours $(67.2 \%)$, and had another paid job (68.7\%). Among those with a second job, most considered the mental health service to be the most consuming $(58.7 \%)$, and had already considered the possibility of changing jobs (47.8\%).

\section{Analysis of the Level of Overall Satisfaction and by Subscales}

The overall level of satisfaction manifested by patients and the staff in regard to the service was classified as moderate, with mean scores of 3.69 and 3.14, respectively. The overall mean score obtained by the family caregivers (4.37) indicates this group was satisfied with the service under study.

Table 1 presents the results from the Kruskal-Wallis test and multiple comparisons concerning the mean scores obtained by the patients in the satisfaction subscales. The analyses showed statistically significant differences between subscales 1 and 3, and between subscales 2 and 3 (values of the differences between ranks are greater than 28.66), indicating that the patients' levels of satisfaction varied according to the aspects assessed.

Table 1

Analysis of the Mean Scores Obtained in the Subscales Addressing Patient Satisfaction (SATIS-BR), According to Kruskal-Wallis Test and Multiple Comparisons

\begin{tabular}{|c|c|c|c|c|}
\hline \multirow{2}{*}{ Subscale } & \multicolumn{4}{|c|}{ Multiple Comparisons: Dif $=26.88^{*}$} \\
\hline & $M(S D)$ & $\operatorname{Dif}(1-2)$ & $\operatorname{Dif}(1-3)$ & $\operatorname{Dif}(2-3)$ \\
\hline 1. Staff expertise and understanding. & $3.96(0.58)$ & 9.62 & $102.78^{*}$ & $112.4^{*}$ \\
\hline 2. Helpfulness of the servisse. & $4.06(0.63)$ & & & \\
\hline 3. Service's physical conditions. & $2.19(0.98)$ & & & \\
\hline Overall scale & $3.69(0.53)$ & & & \\
\hline
\end{tabular}

Note. Kruskal-Wallis bilateral test: Chi-square $=123.613$; degrees of freedom $=2 ; p=.000$; Dif $(1-2)$ differences between the mean ranks of subscales 1 and 2; Dif (1-3) differences between the mean ranks of subscales 1 and 3; Dif (2-3) differences between the mean ranks of subscales 2 and 3. *Value obtained from the expression of multiple comparisons of Kruskal-Wallis test (Siegel \& Castellan, 2006).

The score (3.69) concerning the dimension staff expertise and understanding, assessed by subscale 1 , was higher than the service's appearance and level of comfort, assessed by subscale 3 (2.19). The dimension concerning helpfulness of the service, assessed by subscale 2 presented a higher score (4.06) than the service's appearance and level of comfort, assessed by subscale 3 (2.19).
Table 2 presents the results of the analysis of mean scores obtained in the subscales concerning the family caregiver satisfaction (SATIS-BR) using the Kruskal-Wallis test. The comparative analyses showed no significant statistical differences among the subscales $(p=.08)$. All the dimensions presented average scores of 4 , indicating that family caregivers were equally satisfied with the service's various features. 
Table 2

Analysis of the Mean Scores Obtained in the Family Caregiver Satisfaction (SATIS-BR), According to the Kruskall Wallis Test

\begin{tabular}{lcc}
\hline Subscales & $M(S D)$ & $p$ \\
\hline $\begin{array}{l}\text { 1. Level of family caregiver satisfaction in regard to } \\
\text { the treatment results. }\end{array}$ & $4.45(0.78)$ & .088 \\
$\begin{array}{l}\text { 2. Level of family caregiver satisfaction in regard to } \\
\text { the staff's expertise and helpfulness. }\end{array}$ & $4.30(0.74)$ \\
$\begin{array}{l}\text { 3. Level of family caregiver satisfaction in regard to } \\
\text { the service's privacy and confidentiality. }\end{array}$ & $4.34(0.72)$ \\
Overall scale & $4.37(0.64)$ \\
\hline
\end{tabular}

Note. Kruskall-Wallis: Chi-square $=4.857$; degrees of freedom $=2 ; p=.088$.

Table 3 presents the results of the analysis of the mean scores obtained by the staff on the subscales (SATISBR) according to the Kruskal-Wallis test and multiple comparisons. The results show statistical differences in regard to the comparisons of all four subscales $(p \leq .05)$. The mean scores obtained for most subscales (1,2 and 4) was 3, indicating regular satisfaction with the service. Subscale 3 (Working conditions) was an exception with a mean score of 2, indicating dissatisfaction with the aspects under study. None of the subscales scored 4 or 5 , which would have indicated the staff was satisfied or very satisfied with the aspects under study.

Table 3

Analysis of Mean Scores Obtained in the Subscales Addressing the Staff Satisfactions (SATIS-BR), According to the Kruskal-Wallis Test and Its Multiple Comparisons

\begin{tabular}{|c|c|c|c|c|c|c|c|}
\hline \multirow{3}{*}{ Subscales } & \multicolumn{7}{|c|}{ Multiple Comparisons: Dif $=35.195^{*}$} \\
\hline & \multirow{2}{*}{$M(S D)$} & \multicolumn{6}{|c|}{ Dif } \\
\hline & & $(1-2)$ & $(1-3)$ & $(1-4)$ & $(2-3)$ & $(2-4)$ & $(3-4)$ \\
\hline 1. Quality of care delivery. & $3.39(0.56)$ & 29.45 & $75.21 *$ & $44.57 *$ & $45.76^{*}$ & $74.02 *$ & $119.78^{*}$ \\
\hline 2. Participation in the service. & $3.11(0.67)$ & & & & & & \\
\hline 3. Working conditions. & $2.69(0.53)$ & & & & & & \\
\hline 4. Relationship at work. & $3.87(0.70)$ & & & & & & \\
\hline Overall scale & $3.14(0.48)$ & & & & & & \\
\hline
\end{tabular}

Note. Kruskal-Wallis bilateral test: Chi-square $=84.988$; degrees of freedom $=3 ; p=.000$; Dif (i-j) differences between the mean ranks of subscales i and j; $S D=$ standard deviation. *Value obtained from the expression of multiple comparison of the Kruskal-Wallis test (Siegel \& Castellan, 2006).

The scores of professionals in the dimension concerning the quality of services provided (subscale 1) was higher (3.39) than that obtained in the dimension regarding participation in the service (3.11) and working conditions (2.69). The score (3.11) obtained in the dimension of participation in the service (subscale 2) was higher than the score obtained in the dimension concerning working conditions (2.69). The dimension regarding the relationships established among coworkers at the workplace (subscale 4) presented the highest score (3.87) among the four subscales, that is, higher than the quality of the services provided (3.39), participation in the service (3.11), and working conditions (2.69).

\section{Discussion}

The results showed both convergences and divergences in the dimensions that assessed the level of satisfaction of patients, family caregivers, and the staff of the mental health service. These results reinforce the importance of assessments addressing the perspectives of these stakeholders (Thornicroft \& Tansella, 2010; WHO, 2001).

The results concerning the patient sample that indicate moderate overall satisfaction with the service contradict those of international (Blenkiron \& Hammill, 2003; Gani et al., 2011; Holikatti et al., 2012) and Brazilian studies (Heckert et al., 2006; Kantorski et al., 2009; Silva et al., 2012), which report high levels of satisfaction. One potential explanation for this difference, especially in comparison to Brazilian studies, may be related to the type of service assessed. This study assessed a large community mental health service (CAPS III), while the other Brazilian studies assessed smaller services (CAPS I). These services differ in regard to their capacity, dimensions, number of interventions implemented and professionals. CAPS III are more complex services because they also have psychiatric hospital beds, provide care to patients during psychiatric episodes, allow brief hospitalizations, have 24-hour clinical support, and night shifts. This diversified supply of services may have 
generated overestimated expectations regarding the quality of service. Part of this expectation may not have been met so that patients' satisfaction was only regular. The theoretical model Addressing Expectations used to assess satisfaction, especially in the Contrast Model, explains this kind of finding. According to this model, an individual compares his/ her prior expectations with concrete reality when assessing a service. Low satisfaction results when expectations are higher than the service's performance (Ruggeri, 2010). Another potential explanation is that patients' conditions were stable at the time of data collection and they were able to properly distinguish the service's features, which enabled them to critically assess the quality of service provided. Additionally, the Probing Technique used at the time of data collection in this study may have also contributed to increasing the patients' discriminatory abilities because, in this technique, the patients are asked to justify their responses (Guillemin et al., 1993). The need to present justifications may have contributed to showing the discrepancies between expectations and reality, resulting in a more accurate analysis of this service.

The results concerning the sample of family caregivers contradict the findings of two international studies (Perreault et al., 2011; Stengard et al., 2000), which report high levels of dissatisfaction and corroborate Brazilian studies (Bandeira et al., 2011; Camilo et al., 2012; Santos \& Cardoso, 2014). The family caregivers presented a high level of overall satisfaction and satisfaction according to the service's dimensions. The aforementioned Contrast Model may explain this result. The family caregivers addressed in this study tended to compare the mental health service with Immediate Care Units and Healthcare Units. They highlighted the qualities of the mental health service, such as ease of scheduling consultations, closer proximity to the staff, and greater access to care whenever necessary, which contrasts with the difficulties faced in healthcare services in general. This type of comparison is also reported by a Brazilian study (Bandeira et al., 2011); however, the level of satisfaction manifested by the family caregivers may not necessarily indicate a high quality of service. Mental health care services are compared to services with different objectives, different types of patients, and different care delivery. Mental health care services have specific interventions that are not included in the repertoire of activities of healthcare services in general and the family caregivers seemed to have overlooked these elements.

The staff expressed moderate level of overall satisfaction in regard to the mental health service under study. These results corroborate Brazilian studies (De Marco et al., 2008; Ishara et al., 2014; Rebouças et al., 2007) and contradict those of international studies reporting high levels of dissatisfaction (Evans et al., 2006; Hannigan et al., 2000). The highest mean score concerned the relationship established with coworkers, while the mean scores concerning the service's infrastructure and working conditions were the lowest. Other Brazilian studies (De Marco et al., 2008; Ishara et al., 2014; Rebouças et al., 2007) report similar results. This consensus reveals poor working conditions, such as deficient infrastructure, lack of security, and low salaries, which compromise the delivery of quality care. None of the subscales addressed in this study obtained scores that indicate the staff was satisfied or very satisfied (scores 4 and 5, respectively), while the subscale concerning working conditions obtained the lowest score in comparison to other Brazilian studies (Camilo et al., 2012; De Marco et al., 2008; Ishara et al., 2014; Rebouças et al., 2007). Being satisfied at work is essential for those working in large services, otherwise their actions cannot be efficient; these professionals provide care to patients experiencing psychiatric episodes on a daily basis, which requires a high level of energy and willingness on the part of the staff.

Some similarities were observed in the three samples. The service's appearance and comfort level caused dissatisfaction among patients and workers. Other Brazilian studies also found moderate or low levels of satisfaction among patients (Camilo et al., 2012; Heckert et al., 2006; Kantorski et al., 2009) and workers concerning this aspect (De Marco et al., 2008; Ishara et al., 2014; Rebouças et al., 2007). These findings may be explained by a lack of public investment in the proper maintenance of these services (Andreoli, Almeida-Filho, Martin, Mateus, \& Mari, 2007).

The levels of satisfaction of patients and family caregivers differed in regard to the amount of information provided to the patients and families concerning the disease and treatment. The availability and quantity of information should be seen from a psychoeducational perspective, designed to improve quality of life and treatment adherence, so as to encourage autonomy and involvement with the treatment (Perreault, Katerelos, Sabourin, Leichner, \& Desmarais, 2001). The information provided this way is more coherent with the principles of the Psychiatric Reform. The family caregivers were satisfied with information received; however, $58 \%$ of the patients were moderately satisfied or dissatisfied with this aspect. Other studies (Kantorski et al., 2009; Silva et al., 2012) also found low levels of satisfaction among patients in regard to information received. According to Ruggeri (2010), the quantity and quality of information provided to patients is a predictor of the level of satisfaction. For Perreault et al. (2001), information is one of the dimensions concerning mental health services that determines satisfaction.

This study presents some limitations. The samples were not randomly selected from the target population, which limits the generalization of results. Additionally, this is a crosssectional study,thus monitoring how satisfaction behaves at different points in time over the course of the treatment is not possible. Despite these limitations, this study highlights the importance of assessments from multiple perspectives to obtain information that contributes to the improvement of mental health services.

This study's results highlighted the dissatisfaction of patients in regard to the mental health service's level of comfort, appearance and overall infrastructure and the dissatisfaction of workers in regard to the same aspects and also in regard to working conditions, which agree with the findings of other Brazilian studies. The conclusion is that financial investments are imperative in these services, as is valuing the professionals working in the mental health field. These elements are essential for the Psychiatric Reform to 
effectively become a public health police capable to enable care delivery, social insertion, active citizenship, and quality of life of those using and working in these services.

\section{References}

Andreoli, S. B., Almeida-Filho, N., Martin, D., Mateus, M. D. M. L., \& Mari, J. J. (2007). Is psychiatric reform a strategy for reducing the mental health budget? The case of Brazil. Revista Brasileira de Psiquiatria, 29(1), 43-46. doi:10.1590/S1516-44462006005000032

Bandeira, M. (2014). Princípios norteadores para a avaliação de serviços de saúde mental [Guiding principles for the evaluation of mental health services]. In M. Bandeira, L. A. Lima, \& S. Barroso (Orgs.), Avaliação de serviços de saúde mental: Princípios metodológicos, indicadores de qualidade e instrumentos de medida [Mental health services evaluation: Methodological principles, quality indicators and measurement instruments] (pp. 19-54). Petrópolis, RJ: Vozes.

Bandeira, M., Mercier, C., Perreault, M., Libério, M. M. A., \& Pitta, A. M. F. (2002). Escala de avaliação da satisfação dos familiares com os serviços de saúde mental: SATISBR [The Brazilian mental health services' family satisfaction scale: SATIS-BR]. Jornal Brasileiro de Psiquiatria, 51(3), 153-166.

Bandeira, M., Pitta, A. M. F., \& Mercier, C. (2000). Escalas brasileiras de avaliação da satisfação (SATIS-BR) e da sobrecarga (IMPACTO-BR) da equipe técnica em serviços de saúde mental [The Brazilian mental health services' staff satisfaction scale (SATIS-BR) and staff burden scale (IMPACTO-BR). Jornal Brasileiro de Psiquiatria, 49(4), 105-115.

Bandeira, M., \& Silva, M. A. (2012). Escala de satisfação dos pacientes com os serviços de saúde mental (SATIS$\mathrm{BR}$ ): Estudo de validação [Patients' satisfaction with mental health services scale (SATIS-BR): Validation study]. Jornal Brasileiro de Psiquiatria, 61(3), 124-132. doi:10.1590/S0047-20852012000300002

Bandeira, M., Silva, M. A., Camilo, C. A., \& Felício, C. M. (2011). Satisfação de familiares de pacientes psiquiátricos com os serviços de saúde mental e seus fatores associados [Family satisfaction in mental health services and associated factors]. Jornal Brasileiro de Psiquiatria, 60(4), 284-293. doi:10.1590/S004720852011000400009

Barroso, S. (2014). Sobrecarga de familiares de pacientes psiquiátricos [Family burden of psychiatric patients]. In M. Bandeira, L. A. Lima, \& S. Barroso (Orgs.). Avaliação de serviços de saúde mental: Princípios metodológicos, indicadores de qualidade e instrumentos de medida [Mental health services evaluation: Methodological principles, quality indicators and measurement instruments] (pp. 187-216). Petrópolis, RJ: Vozes.

Blenkiron, P., \& Hammill, C. A. (2003). What determines patients' satisfaction with their mental health care and quality of life? Postgraduate Medical Journal, 79(932),
337-340. doi:10.1136/pmj.79.932.337

Camilo, C. A., Bandeira, M., Leal, R. M. A. C., \& Scalon, J. D. (2012). Avaliação da satisfação e sobrecarga em um serviço de saúde mental [Satisfaction and burden evaluation in a mental health service]. Cadernos de Saúde Coletiva, 20(1), 82-92. Retrieved from http:// www.cadernos.iesc.ufrj.br/cadernos/images/csc/2012_1/ artigos/CSC_v20n1_82-92.pdf

Cardoso, C. (2014). Qualidade de vida na esquizofrenia: Atualidades e perspectivas para o Brasil [Quality of life in schizophrenia: Present time and perspectives for Brazil]. In M. Bandeira, L. A. Lima, \& S. Barroso (Orgs.), Avaliação de serviços de saúde mental: Princípios metodológicos, indicadores de qualidade $e$ instrumentos de medida [Mental health services evaluation: Methodological principles, quality indicators and measurement instruments (pp. 159-186). Petrópolis, RJ: Vozes.

Contandriopoulos, A.-P., Champagne, F., Potvin, L., Denis, J.-O., \& Boyle, P. (1994). Saber preparar uma pesquisa [Know how to prepare a research] (S. R. Souza, Trad.). São Paulo, SP: Hucitec; Rio de Janeiro, RJ: Abrasco.

Costa, M. G. S. G., Figueiró, R. A., \& Freire, F. H. M. A. (2014). O fenômeno da cronificação nos centros de atenção psicossocial: Um estudo de caso [The phenomenon of chronification on psychosocial aid centers: A case study]. Temas em Psicologia, 22(4), 839-851. doi:10.9788/ TP2014.4-13

Delgado, P. G. G., Schechtman, A., Weber, R., Amstalden, A. F., Bonavigo, E., Cordeiro, F., . . Grigolo, T. (2007). Reforma psiquiátrica e política de saúde mental no Brasil [Psychiatric reform and mental health policy in Brazil]. In M. F. Mello, A. A. F. Mello, \& R. Kohn (Orgs.), Epidemiologia da saúde mental no Brasil [Epidemiology of mental health in Brazil] (pp. 39-83). Porto Alegre, RS: Artmed.

De Marco, P. F., Cítero, V. A., Moraes, E., \& Nogueira-Martins, L. A. (2008). O impacto do trabalho em saúde mental: Transtornos psiquiátricos menores, qualidade de vida e satisfação profissional [Job impact on mental health workers: Minor psychiatric disorders, quality of life and job satisfaction]. Jornal Brasileiro de Psiquiatria, 57(3), 178183. doi:10.1590/S0047-20852008000300004

Donabedian, A. (1990). The seven pillars of quality. Archives of Pathology \& Laboratory Medicine, 114(11), 1115-1118.

Einsen, S. V. (2010). Patient satisfaction and perceptions care. In W. W. IsHak, T. Burt, \& L. I. Sederer (Eds.), Outcome measurement in psychiatry: A critical review (pp. 303320). Washington, DC: American Psychiatric Publishing.

Evans, S., Huxley, P., Gately, C., Webber, M., Mears, A., Pajak, S., . . Katona, C. (2006). Mental health, burnout and job satisfaction among mental health social workers in England and Wales. The British Journal of Psychiatry, 188(1), 75-80. doi:10.1192/bjp.188.1.75

Gani, N., Saeed, K., Minhas, F. A., Anjuman, N., Waleed, M., \& Fatima, G. (2011). Assessment of patient satisfaction with mental health services in a tertiary care setting. Journal of Ayub Medical College Abbottabad, 23(1), 
43-46. Retrieved from http://www.ayubmed.edu.pk/ JAMC/23-1/Gani.pdf

Guillemin, F., Bombardier, C., \& Beaton, D. (1993). Crosscultural adaptation of health-related quality of life measures: Literature review and proposed guidelines. Journal of Clinical Epidemiology, 46(12), 1417-1432. doi:10.1016/0895-4356(93)90142-N

Hannigan, B., Edwards, D., Coyle, D., Fothergill, A., \& Burnard, P. (2000). Burnout in community mental health nurses: Findings from the all Wales stress study. Journal of Psychiatry and Mental Health Nursing, 7(2), 127-134. doi:10.1046/j.1365-2850.2000.00279.x

Heckert, U., Teixeira, L. S., \& Trindade, A. S. (2006). Avaliação da satisfação dos usuários do Centro Regional de Referência em Saúde Mental (CRRESAM) da região central de Juiz de Fora, MG [The satisfaction of mental health reference regional center's users (CRRESAM) on the central region at Juiz de Fora, MG]. HU Revista, 32(1), 15-19.

Holikatti, P. C., Kar, N., Mishra, A., Shukla, R., Swain, S. P., \& Kar, S. (2012). A study on patient satisfaction with psychiatric services. Indian Journal of Psychiatry, 54(4), 327-332. doi:10.4103/0019-5545.104817

Ishara, S., Bandeira, M., \& Zuardi, A. W. (2014). O impacto do trabalho em profissionais de serviços de saúde mental [The impact of work in mental health care professionals]. In M. Bandeira, L. A. Lima, \& S. Barroso (Orgs.), Avaliação de serviços de saúde mental: Princípios metodológicos, indicadores de qualidade e instrumentos de medida [Mental health services evaluation: Methodological principles, quality indicators and measurement instruments] (pp. 217240). Petrópolis, RJ: Vozes.

Kantorski, L. P. (2012). Os desafios da avaliação no campo da saúde mental [The challenges of evaluation in the field of mental health]. Revista Eletrônica de Enfermagem, 14(1), 14-15. doi:10.5216/ree.v14i1.27472

Kantorski, L. P., Jardim, V. R., Wetzel, C., Olschowsky, A., Schneider, J. F., Heck, R. M, . . Saraiva, S. S. (2009). User satisfaction with psychosocial healthcare services, Southern Brazil. Revista de Saúde Pública, 43(Supl. 1), 29-35. doi:10.1590/S0034-89102009000800006

Lasalvia, A., Boggian, I., Bonetto, C., Saggioro, V., Piccione, G., Zanoni, C., . . . \& Lamonaca, D. (2012). Multiple perspectives on mental health outcome: Needs for care and service satisfaction assessed by staff, patients and family members. Social Psychiatry and Psychiatric Epidemiology, 47(7), 1035-1045. doi:10.1007/s00127011-0418-0

Leal, R. M. A. C., Bandeira, M. B., \& Azevedo, K. R. N. (2012). Avaliação da qualidade de um serviço de saúde mental na perspectiva do trabalhador: Satisfação, sobrecarga e condições de trabalho dos profissionais [Evaluation of a mental health service quality in the perspective of their professionals: Satisfaction, burden and work conditions]. Psicologia: Teoria e Prática, 14(1), 15-25. Retrieved from: http://pepsic.bvsalud.org/pdf/ptp/ v14n1/v14n1a02.pdf
Lei n. 10.216, de 6 de abril de 2001. (2001, 9 de abril). Dispõe sobre a proteção e os direitos das pessoas portadoras de transtornos mentais e redireciona o modelo assistencial em saúde mental [Provides for the protection and rights of people with mental disorders and redirects the mental health care model]. Diário Oficial da União, seção 1.

Melo, A. P. S., \& Guimarães, M. D. C. (2005). Factors associated with psychiatric treatment dropout in a mental health reference center, Belo Horizonte. Revista Brasileira de Psiquiatria, 27(2), 113-118. doi:10.1590/ S1516-44462005000200008

Oliveira, M. A. F., Cestari, T. Y., Pereira, M. O., Pinho, P. H., Gonçalves, R. M. D. A., \& Claro, H. G. (2014). Processos de avaliação de serviços de saúde mental: Uma revisão integrativa [Assessment procedures of mental health services: An integrative review]. Saúde em Debate, 38(101), 368-378. doi:10.5935/0103-1104.20140034

Organização Mundial da Saúde.(1994). CID-10: Classificação estatística internacional de doenças e problemas relacionados à saúde [International classification of diseases and related health problems statistics] (Centro Colaborador da OMS para a Classificação de Doenças em Português, Trans., 10th ed.). São Paulo, SP: Edusp.

Pelisoli, C., Moreira, A. K., \& Kristensen, C. H. (2007). Avaliação da satisfação e do impacto da sobrecarga de trabalho em profissionais de saúde mental [Assessment of satisfaction and impact of work overload among mental health professionals]. Mental, 5(9), 63-78. Retrieved from http://pepsic.bvsalud.org/pdf/mental/v5n9/v5n9a05.pdf

Perreault, M., Katerelos, T. E., Sabourin, S., Leichner, P., \& Desmarais, J. (2001). Information as a distinct dimension for satisfaction assessment of outpatient psychiatric services. International Journal of Health Care Quality Assurance Incorporating Leadership in Health Services, 14(3), 111-120. doi:10.1108/09526860110391586

Perreault, M., Rousseau, M., Provencher, H., Roberts, S., \& Milton, D. (2011). Predictors of caregiver satisfaction with mental health services. Community Mental Health Journal, 48(2), 232-237. doi:10.1007/s10597-011-9403-z

Rebouças, D., Legay, L. F., \& Abelha, L. (2007). Satisfação com o trabalho e impacto causado nos profissionais de serviço de saúde mental [Job satisfaction and work impact among providers of a mental health servisse]. Revista de Saúde Pública, 41(2), 244-250. doi:10.1590/ S0034-89102007000200011

Ruggeri, M. (2010). Satisfaction with mental health services. In G. Thornicroft \& M. Tansella (Eds.), Mental health outcome measures (pp. 99-115). London, United Kingdom: RCPsych.

Santos, A. F. O., \& Cardoso, C. L. (2014). Familiares cuidadores de usuários de serviço de saúde mental: Satisfação com serviço [Family caregivers of mental health service users: Satisfaction with the service]. Estudos de Psicologia (Natal), 19(1), 13-21. doi:10.1590/ S1413-294X2014000100003

Santos, A. M., Cardoso, D. A. J., Vieira, D. P. B., Araújo, F. C., Farias, H. S., Mota, S. P., . . \& Bahia, S. H. A. (2011). 
Análise dos níveis de satisfação de trabalhadores de saúde mental de um hospital público de referência psiquiátrica em Belém, PA [Analysis of levels of satisfaction of mental health workers of a reference psychiatric public hospital in Belém, PA]. Revista Baiana de Saúde Pública, 35(4), 813-825. Retrieved from http://inseer.ibict.br/rbsp/index. php/rbsp/article/viewFile/256/pdf_69

Siegel, S., \& Castellan, J. N., Jr. (2006). Estatística nãoparamétrica para ciências do comportamento [Non parametric statistics for behavioral sciences] (S. I. C. Carmona, Trans., 2nd ed.). Porto Alegre, RS: Artmed.

Silva, M. (2014). Satisfação dos usuários com os serviços de saúde mental [User satisfaction with mental health services]. In M. Bandeira, L. A. Lima, \& S. Barroso (Orgs.), Avaliação de serviços de saúde mental: Princípios metodológicos, indicadores de qualidade $e$ instrumentos de medida [Mental health services evaluation: Methodological principles, quality indicators and measurement instruments] (pp. 55-86). Petrópolis, RJ: Vozes.

Silva, M. A., Bandeira, M., Scalon, J. D., \& Quaglia, M. A. C. (2012). Satisfação dos pacientes com os serviços de saúde mental: A percepção de mudanças como preditora [Patients' satisfaction with mental health services: The perception of changes as predictor]. Jornal Brasileiro de Psiquiatria, 61(2), 64-71. doi:10.1590/S004720852012000200002

Silva, N. D. S., Melo, J. M., \& Esperidião, E. (2012). Avaliação dos serviços de assistência em saúde mental brasileiros: Revisão integrativa da literatura [Assessment of mental health services in Brazil: An integrative literature review]. Revista Mineira de Enfermagem, 16(2), 280288. doi:S1415-27622012000200018

Snedecor, G. W., \& Cochran, W. G. (1971). Métodos estatísticos [Statistical methods] (J. A. Reinosa Fuller, Trans.). México: Continental.

Stengard, E., Honkonen, T., Koivisto, A. M., \& Salokangas, R. K. R. (2000). Satisfaction of caregivers of patients with schizophrenia in Finland. Psychiatric Services, 51(8), 1034-1039. doi:10.1176/appi.ps.51.8.1034

Tessler, R. C., \& Gamache, G. (2000). Family experiences with mental illness. Westport, CT: Greenwood.

Thornicroft, G., \& Tansella, M. (2010). Boas práticas em saúde mental comunitária [Better mental health care] (M. T. Muramoto, Trans.). Barueri, SP: Manole.

World Health Organization. (2001). The world health report: 2001: Mental health: New understanding, new hope. Geneva, Switzerland: WHO.

Kênia Izabel David Silva de Resende is a M.S. in Psychology from Universidade Federal de São João del-Rei and a Professor of the Centro Universitário de Lavras (UNILAVRAS).

Marina Bandeira is a Professor of the Universidade Federal de São João del-Rei.

Daniela Carine Ramires Oliveira is a Professor of the Universidade Federal de São João del-Rei.
Received: Feb. 18, 2015

1st Revision: July 8, 2015

Approved: Sep. 2, 2015
How to cite this article:

Resende, K. I. D. S., Bandeira, M., \& Oliveira, D. C. R. (2016). Assessment of patients, families and staff satisfaction in a mental health service. Paidéia (Ribeirão Preto), 26(64), 245-253. doi:10.1590/1982-43272664201612 